\title{
Prevalence and characteristics of diabetic foot ulcerations in Western Sydney
}

\author{
Norafizah Haji Zaine ${ }^{*}$, Kerry Hitos ${ }^{2}$, John Fletcher ${ }^{2}$, Mauro Vicaretti ${ }^{2}$, Joshua Burns ${ }^{1,2}$ \\ From Australasian Podiatry Council Conference 2013 \\ Sydney, Australia. 2-5 June 2013
}

\section{Background}

Patients with diabetes are at high risk of developing foot ulcerations that can develop into non-healing wounds. Recent studies suggest that the lifetime risk of developing a diabetic foot ulcer is as high as $25 \%$. The aim of this study was to determine the prevalence and characteristics of diabetic foot ulcerations (DFUs) at the Foot Wound Clinic at Westmead Hospital.

\section{Methods}

In 2011, 318 patients were extracted for analysis from the Westmead Hospital Foot Wound Database on new diabetic foot ulcerations. Data on demographics, socioeconomic, co-morbidities, foot ulcer characteristics and treatment were recorded on a standardised form adapted from the Eurodiale studies. Patients with Type $2 \mathrm{DM}$ and Type $1 \mathrm{DM}$ in outpatient clinics were included in the study.

\section{Results}

In total, $74.5 \%$ of patients were diabetics. Demographics of diabetic foot ulcerations were: male (66.2\%), mean age 67 years (range: 19-95 years), low socio-economic status (mean ABS postcode score 969, SD 119). DFU characteristics were: cross sectional area of $684.1 \mathrm{~mm}^{2}$, volume of $6.3 \mathrm{~cm}^{3}, 33 \%$ on the forefoot, $67.9 \%$ acute and $12.3 \%$ chronic. The University of Texas $(\mathrm{U} / \mathrm{T})$ foot classification was category 6: the ischaemic limb (61.5\%); category 4A: neuropathic wounds (34.6\%) and others (3.9\%). Predominant U/T wound types: $29.4 \% 1 \mathrm{~A}$ and $12.8 \% 1 \mathrm{C}$.

\footnotetext{
* Correspondence: nhaj2406@uni.sydney.edu.au

${ }^{1}$ Arthritis and Musculoskeletal Research Group, The University of Sydney, Sydney, NSW, 2137, Australia

Full list of author information is available at the end of the article
}

\section{Conclusion}

Diabetic foot ulcers are prevalent in Western Sydney and are more likely to affect older males from a lower socioeconomic background. Understanding the other factors related to diabetic foot ulcers will assist the podiatrist in providing a more targeted management plan.

\section{Author details}

${ }^{1}$ Arthritis and Musculoskeletal Research Group, The University of Sydney, Sydney, NSW, 2137, Australia. ${ }^{2}$ Foot Wound Clinic, Department of Surgery, The University of Sydney, Westmead Hospital, NSW, 2145, Australia.

Published: 31 May 2013

\section{doi:10.1186/1757-1146-6-S1-013}

Cite this article as: Zaine et al:: Prevalence and characteristics of diabetic foot ulcerations in Western Sydney. Journal of Foot and Ankle Research 2013 6(Suppl 1):013.

\section{Submit your next manuscript to BioMed Central and take full advantage of: \\ - Convenient online submission \\ - Thorough peer review \\ - No space constraints or color figure charges \\ - Immediate publication on acceptance \\ - Inclusion in PubMed, CAS, Scopus and Google Scholar \\ - Research which is freely available for redistribution \\ Submit your manuscript at www.biomedcentral.com/submit \\ C Biomed Central}

(c) 2013 Zaine et al; licensee BioMed Central Ltd. This is an Open Access article distributed under the terms of the Creative Commons 